\title{
DEVELOPMENT OF A SMARTPHONE DEVICE FOR READING AIMED AT LOW- VISION PEOPLE
}

\section{DESENVOLVIMENTO DE UM DISPOSITIVO SMARTPHONE DE LEITURA PARA PESSOAS COM BAIXA VISÃO}

\author{
Bruno Procópio da Silva ${ }^{1}$ \\ Alessandro Correa Mendes ${ }^{2}$ \\ Fernanda Púpio Silva Lima ${ }^{3}$ \\ Ana Paula Pinto 4 \\ Gabriela Aparecida da Silveira Souza ${ }^{5}$ \\ Rodrigo Alvaro Brandão Lopes-Martins ${ }^{6}$ \\ Mário Oliveira Lima7
}

\begin{abstract}
Many people with total or partial visual impairment can use assistive technology (AT) to facilitate daily living activities. Smartphones and, especially, their applications, can be a tool of easy access and applicability as AT. The aim of this study was to develop an application for use on a smartphone or tablet to improve the visual ability of people with low visual acuity. The software, called Oftcam, was developed using the ANDROID operating system, written in Java Android under the Java version JDK 1.7, supporting the minimum version of Android 2.2. Its operating mechanism includes capturing and adjusting the image of interest to the users according to their needs: expansion, change of background and decentralization of the image of interest. The development of this free, easy-to-handle application will provide the possibility of integration between the user and the auxiliary professional, being, in practice, a mobile resource of health. Considering that most people have an increasing access to phones and tablets, we believe the use of this application is a good alternative to integrate the need and practicality in the daily lives of the visually impaired people.
\end{abstract}

Keywords: Visual impairment. Low vision. Rehabilitation. Assistive technology. Software.

Resumo: Muitas pessoas com deficiência visual total ou parcial podem recorrer à tecnologia assistiva (TA) para facilitar as atividades da vida diária. Os smartphones e, principalmente, seus aplicativos podem ser uma ferramenta de fácil acesso e aplicabilidade para a tecnologia assistiva (TA) O objetivo deste estudo foi desenvolver um aplicativo para uso em smartphone ou tablet para aprimorar a capacidade de visualização de pessoas com baixa acuidade visual. O software, chamado Oftcam, foi desenvolvido por meio do sistema operacional ANDROID, escrito em Java Android sob a versão do Java JDK 1.7, suportando a versão mínima do Android 2.2. Seu mecanismo operacional inclui a captura e o ajuste da imagem de interesse do usuário de acordo com suas necessidades: ampliação, mudança de fundo e descentralização da imagem de interesse. O desenvolvimento desta ferramenta gratuita, de fácil

\footnotetext{
1 Universidade do Vale do Paraíba - Univap, E-mail: brunoprocopio7@hotmail.com.

2 Universidade do Vale do Paraíba - Univap, E-mail: alcomen@univap.br.

3 Universidade do Vale do Paraíba - Univap, E-mail: fpupio@univap.br.

4 Universidade do Vale do Paraíba - Univap, E-mail: apaula@outlook.com.br.

5 Universidade do Vale do Paraíba - Univap, E-mail: gabrielasouza507@yahoo.com.br.

6 Universidade Brasil, E-mail: ralopesmartins@gmail.com.

7 Universidade do Vale do Paraíba - Univap, E-mail: mol@univap.br.
} 
manuseio proporcionará a possibilidade de integração entre o usuário e o profissional auxiliar, sendo na prática um recurso móvel de saúde. Considerando que a maioria das pessoas tem cada vez mais telefones ou tablets, acreditamos que o uso desse aplicativo seja uma boa alternativa para integrar a necessidade e a praticidade no dia a dia dos deficientes visuais.

Palavras-chave: Deficiência visual. Baixa visão. Reabilitação. Tecnologia assistiva. Software.

Data de submissão: 09.09.2020

Data de aprovação: 28.04.2021

Identificação e disponibilidade:

https://revista.univap.br/index.php/revistaunivap/article/view/2341,

http://dx.doi.org/10.18066/revistaunivap.v27i56.2341

\section{INTRODUCTION}

The eye is an important sensory organ that influences people's quality of life (CYPEL et al., 2017). Approximately 45 million people worldwide are blind (PIZZARELLO et al., 2004) and 191 million people presented moderate to severe visual impairments in 2010 (STEVENS et al., 2013).

Low visual acuity (LVA) is a significant cause of sensory impairment, causing approximately $90 \%$ of deprivation of all patient's perceptions. Visual impairment has a significant impact on the quality of life of the population, including work and relationships. Almost half of the visually impaired subjects feel isolated from other people and from the surrounding environment (HAKOBYAN et al., 2013). LVA affects both young and elderly people, and may occur over short or long distances (STUMP, 2011).

The World Health Organization (WHO) defines low vision or sub-normal vision as the measure of visual acuity, in the best eye, with the best optical correction, less than 0.3 decimals or $20 / 60$ (Snellen fraction) and greater than or equal to 0.05 or $20 / 400$. In the presence of visual field impairment, WHO recommends, for low vision, that the visual field be less than or equal to 20 degrees, and greater than 5 degrees, at its largest diameter, around the fixation point (WHO, 2016).

Considering the widespread number of eye diseases, the number of affected people has significantly increased in the last decade. Despite the pharmacological and surgical advances in ophthalmology, many eye diseases continue to cause permanent visual deficits, which hinders daily life activities (DLAs). The most varied DLAs and the specific needs of these people with vision impairments promote the increase in targeted rehabilitation measures, to compensate for the limitations and to optimize the residual vision (TRAUZETTEL-KLOSINSKI, 2011).

According to the latest IBGE Census (2010), 45.6 million people reported having at least one type of disability, corresponding to $23.9 \%$ of the Brazilian population. The visual deficiency was the most pointed, reaching $18.8 \%$ of the population.

Despite the existing therapeutic resources, chronic conditions and permanent deficiencies may exist, and dealing with their consequences is one of the roles of rehabilitation medicine, in which ophthalmology is included (COLENBRANDER; FLETCHER, 2003).

Nowadays, assistive technology (AT) has contributed to enhance the functional 
skills of people with disabilities for the promotion of more independence. The integration of the capabilities of AT interaction with the user is very significant. The important factors for this are related to the fact they increase the mechanisms of the available assistive technology, also implementing the capacity of understanding and control by the user (COWAN et al., 2012). Advances in the field of hardware and software can also be included.

Some examples of AT are sensors for the early detection of obstacles (ONG; ZHANG; NEE, 2013), assistive listening devices (WITTICH; SOUTHALL; JOHNSON, 2015), sonification to provide access to geographic maps (DELOGU et al., 2010) and others, that improve the quality of life of people with visual dysfunction by facilitating daily activities.

Advances have also occurred in the field of hardware and software (COWAN et al., 2012). Smartphones, and particularly their applications, have revolutionized eye care and hence vision, but a low frequency of use of these features, as well as their interaction, has been noted among physicians and patients (CHENG; CHAKRABARTI; KAM, 2013).

With the increasing use of technological resources such as smartphones and tablets, there is a great opportunity and need to develop specific devices for the visually impaired people (STUMP, 2011). It is known that the access to AT allows people with visual impairment to improve their communication, mobility and perception of the environment. In many cases the use of technology is the only way for people with communication difficulties to connect with the outside world (ALVES et al., 2009). The development of an ophthalmology APP for smartphones may facilitate patient care, data analysis and communication with the doctor (STANZEL; MEYER, 2012).

The present study aims to develop a smartphone or tablet application with the principle of assistive technology for individuals with low vision. Additionally, we developed an application with the ANDROID operating system for use in mobile phones or tablets to facilitate the availability of an assistive technology resource for the visually impaired people in a quick, practical and accessible way through Google Play.

\section{MATERIAL AND METHODS}

This work was conducted in the Laboratory of Sensory Motor Rehabilitation Engineering of the University of Vale do Paraíba - Univap. The name chosen for the developed application was Oftcam, the union of the terms "Ophthalmology" and "camera". This device will be used by people with visual impairment, through a camera already available in smartphones or tablets sold on the market.

Oftcam, an application for use on a smartphone or tablet by the ANDROID operating system, works with the camera of the electronic device where the image of the user of the application is captured and can be modified according to the interests of the user, such as image magnification, change in the background of the image, and decentralization of the image of interest. These commands can be performed by the login screen or via the voice command in Google Play.

For the development of the application, the Android platform was used because it is the most popular operating system for smartphones and tablets, thus covering a greater number of users. We used the Eclipse Kepler development IDE (Android Developer tools) which is made of the SDK for Android development. The application template was written in Java Android under the Java JDK version 1.7, supporting the minimum version of API 8 Android 2.2, maximum API 22 Android 5.1.1, being structured in version API 15 Android 4.0.3. This application was initially developed in 
the Portuguese language.

All speech recognition features, such as converting speech to written text or text information converted to a voice assistant, were developed using a Google Android Library, the Android.speech.RecognizerIntent and Android.speech.tts.TextToSpeech, respectively.

For the manipulation of the camera features, the Android hardware libraries were used; the camera was used for object manipulation, android prep Preference Manager and android content Shared Preferences to save configuration preferences, as well as android view Surface Holder to control the camera lifecycle.

This application was registered as a patent at the National Institute of Industrial Property (INPI) of Brazil, under the registration number BR512017001088-9.

\section{SUMMARY OF USAGE}

The potential user must log in Google Play Store and search for the Oftcam app, then download it.

In the first access, the user must fill in the personal data to be able to access the application. In the subsequent accesses, this filling will not be necessary.

After user login, the application is available with all its functions. By pointing the device's rear camera (either cell phone or tablet) at a document or other image field of interest, the user can request what they want either by voice command or typing a request, to zoom in/out.

In addition to the zoom options, the application can also modify brightness, and the user can increase or decrease brightness; invert background color; resize the screen (decrease the right screen or decrease the left screen). All of this can be performed by voice command or writing these commands.

The flow chart of use in the application Oftcam is shown in Figure 1. It must be emphasized that the language of the application is Portuguese, and for this reason, the commands are in the written language. 


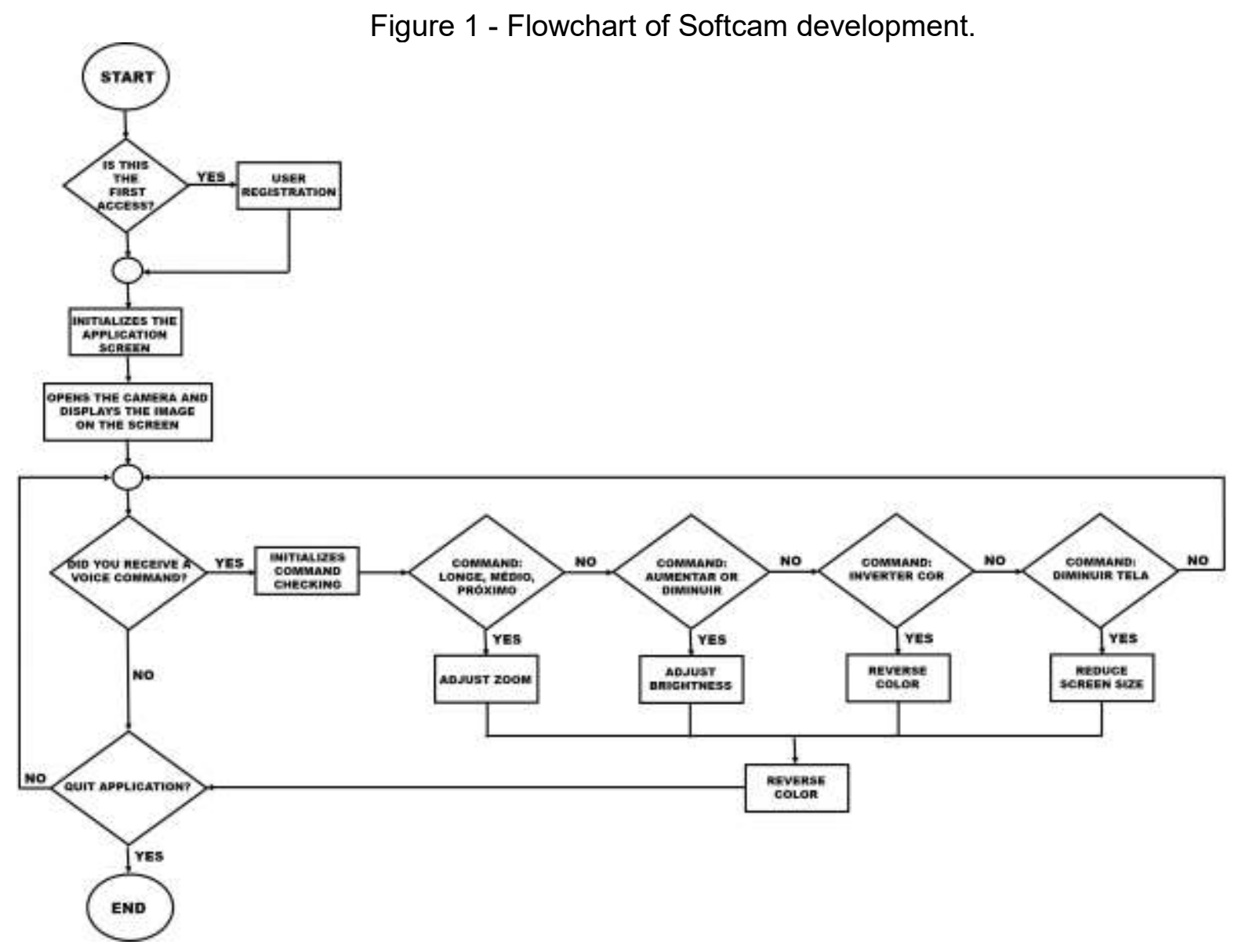

Source: The authors.

\section{RESULTS AND DISCUSSION}

The application is available for free access by the Google Play system (Figure 2). It must be accessed by a smartphone or tablet compatible with the Android operating system. 
Figure 2 - Access interface for the google play system.

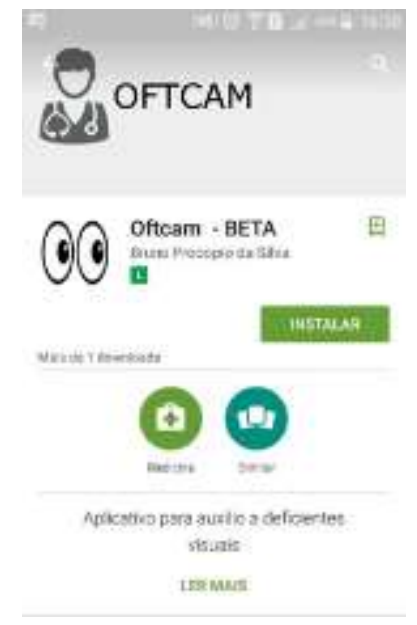

Source: The authors.

It is easy to access and simple to handle, the commands can be requested either verbally or typed. In the first run by the user, a registration screen will be started and will inform by voice command that it is the first execution and that a registration is necessary (Figure 3). Then, it will also be informed by voice command whether the registration will be performed by voice or text. If the choice is "voice", the registration instruction will be informed, asking the user to click on the screen every time they want the next question in the questionnaire to be performed. Right after the click on the screen, the application will sequentially make a questionnaire that should be answered immediately after the question asked (also by voice command). These questions are the name of the user, place of birth, date of birth, level of education and identification of the greatest degree of vision difficulty (near, far or both).

Figure 3 - Softcam Registration.

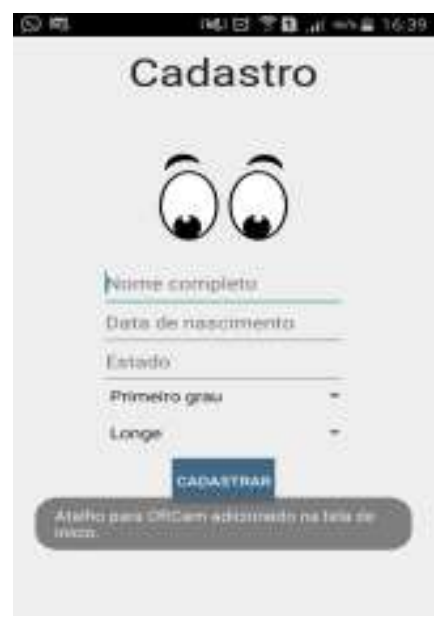

Source: The authors.

As soon as the application finishes listening to the user's response, it will ask for the confirmation of the information heard, which will be confirmed and written at the respective field on the screen with the voice command "YES". If the information is not confirmed, on the following touch on the screen the same question will be repeated, 
otherwise the next question will be informed. At any time, the user can edit the information written by the application in the registration fields on the screen. In cases where the user chooses the registration by text, even if they click in the empty spaces of the screen, the voice command will not be activated, and the registration will be completed after all fields are manually filled. The "START" button will only register and release the main application screen when all fields are filled, either by voice command or manually typed.

In the second execution of the user, the registration will no longer be necessary, and the user will be directly redirected to the reading screen, which will become the active screen.

The reading screen consists in a screen that displays all images captured by the rear camera of the phone or tablet. When clicking on the screen, the voice command will be triggered, and the following commands are expected.

To zoom in/out, the voice commands are: "longe" to zoom out, "médio" to obtain the maximum zoom provided by the camera divided by 2, "próximo" to obtain the maximum zoom, "plus" to zoom in $1 \mathrm{x}$ and "less" to zoom out $1 \mathrm{x}$.

For brightness, the voice commands are: "aumentar brilho" to increase screen luminosity / brightness, "diminuir brilho" to decrease screen luminosity / brightness.

For color, the voice commands are: "Inverter cor" to reverse the colors (from normal to inverted and vice-verse). Example: from a white background with dark writing to a dark background with light writing.

To resize the screen, the voice commands are: "diminuir tela" to reduce the screen by half ( $50 \%)$, and "aumentar tela" to return the screen to the default. There are the right and left variations, with the command "diminuir tela direita" to resize the screen by half $(50 \%)$ and redirect it to the right side of the display. The same occurs for the commands "side" and "diminuir tela esquerda".

Figure 4 shows the screen of the field of interest and the application commands.

Figure 4 - Application commands.

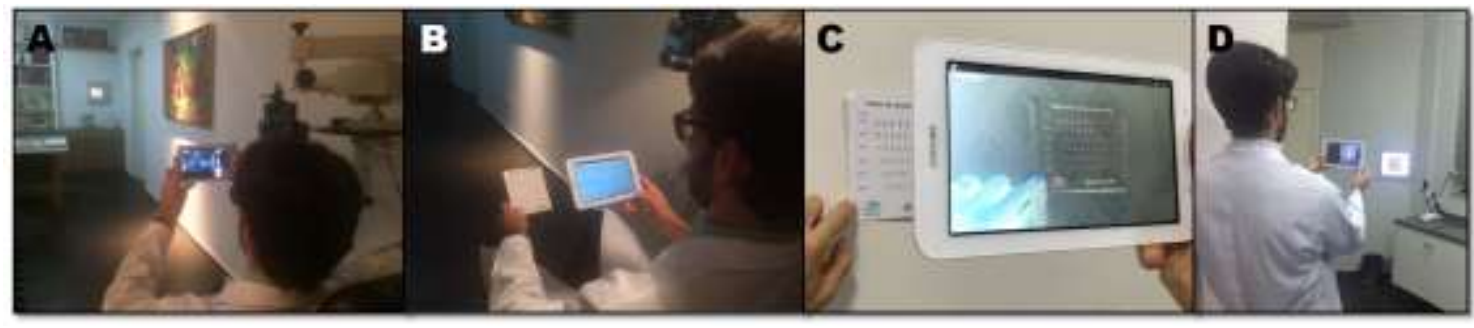

Legend: Oftcam application commands. $A=$ Screen capturing the environment of interest; $B=Z$ Zoom function; $C$ = Invert color function; $D$ = Resize screen. Source: The authors.

Each time the application terminates, or a command to change the configuration is executed, a log is generated with the name of the user and the time of usage for each configuration, and how long the application has been used.

The application, Oftcam, was tested by the lead researcher. A Samsung model tablet was used, starting the initial screen after the registration performed in the first access as described above. An object was placed at a distance of 6 meters to test the distance of vision, and at $40 \mathrm{~cm}$ for a closer view at the test for the application of the zoom function. Standard distances were used for the examination of visual acuity in the near and far in a routine eye examination. The function "maior/menos brilho" was also used in the test for the brightness function. The commands for color inversion and image repositioning were tested both to the 
right and to the left.

\section{DISCUSSION}

The number of people with some type of disability is significant, as described by IBGE in 2010. In particular, LVA, presented in this study, needs mechanisms capable of optimizing the potential of vision still existing in the people affected by this dysfunction.

Since most people have an increasing use of personal phones or tablets for their daily routine, we saw as a good alternative the use of an application that could integrate need and practicality as an assistive technology for the visually impaired people.

A key advantage of using mobile devices to provide assistive technologies is the practical way of running many of the platforms. Devices or applications that are embedded in conventional equipment, such as a mobile phone, can help individuals feel less stigmatized or labeled. In addition, support systems are generally adaptable across multiple mobile platforms and can withstand multiple shortcomings (HAKOBYAN et al. 2014).

The continuous advancements in mobile technologies have made the capture of information, interpretation and understanding of what is happening around visually impaired people increasingly viable. This information can be used to improve the level of independence, mobility and quality of life (HAKOBYAN et al. 2014).

It is important to implement AT in different segments of the health area. The promising aspects of this type of technology, both in developed countries and in developing countries, have been evidenced. Information technology has become an important resource in the lives of people with visual impairments. The use of assistive technology is not seen as an inhibiting factor for these people, unlike other traditional methods (THOMAS et al., 2014).

The use of applications as a healthcare method, especially for the visually impaired people, has a great potential to increase the residual visual capacity of these people, especially with the growth in the use of smartphones and new technologies to be created (MEYER et al., 2012).

Data show a growing use of applications for eye care and, hence, vision. Applications tend to become more consistent with this trend, and a growing descriptive literature has been demonstrating the versatility and ability of smartphones as useful clinical adjuncts in ophthalmology (CHENG; CHAKRABARTI; KAM, 2014).

This study was conducted to demonstrate the applicability of tele-rehabilitation applied by the ophthalmic technician or optometrist to 10 low-vision patients who received a handheld magnification device for reading. The participants reported that the quality of the video was from excellent to good, and eight of the 10 reported that the use of their magnifying glass improved after tele-rehabilitation (BITTNER et al., 2018).

Despite the rapid emergence of applications in ophthalmology, there is a low number of professionals involved in the development of these applications and a meager number of clinical evaluations performed after using these features. There is a clear need for evidence-based application principles and standards to be adopted in this emerging area of eye care, guiding the development of high-quality applications for future mobile health practice (CHENG; CHAKRABARTI; KAM, 2014).

The main focus of this research from the outset was to develop a simple application for the user. It is believed that the developed application can be a good resource for assistive technology for the visually impaired people. The direct touch on 
the screen of the electronic device used, and the execution of the desired action by voice command, have a great practicality, because it does not need good vision to execute the desired command. It was also noted that the quality of the camera of the electronic device has a great influence on the quality of the image generated.

The mode of user-physician interaction can be improved in future studies. Du Toit et al (2018) reported that the increase in the accessibility of people with disabilities to innovative assistive technology can significantly increase their quality of life.

For the development of the application proposed in this study, there was the integration of professionals from different areas, such as: physiotherapy and rehabilitation, computer engineering, biomedical engineering and medicine. The next phase of implementation of the application will be the test in patients with low vision, of diverse ages, and who do not present limitations for the use of tablets or smartphones.

\section{CONCLUSION}

The developed application was Oftcam, through the ANDROID platform, for use in smartphones and tablets. This technology is aimed at the visually impaired people, with the convenience of using voice command.

\section{ACKNOWLEDGMENT}

This study was financed in part by the Coordenação de Aperfeiçoamento de Pessoal de Nível Superior - Brasil (CAPES) - Finance Code 001.

\section{REFERENCES}

ALVES, C. C. Et al. Assistive technology applied to education of students with visual impairment. Rev. Panam. Salud Publica, v. 26, n. 2, p. 148-152, 2009.

BITTNER, A. K., et al. Feasibility of Telerehabilitation for Low Vision: Satisfaction Ratings by Providers and Patients. Optom. Vis. Sci., v. 95, n. 9, p. 865-872, 2018.

CHENG, N.; CHAKRABARTI, R.; KAM, J. Iphone applications for eye care professionals: A review of current capabilities and concerns. Telemedicine and ehealth., v. 20, n. 4, p. 385-7, 2014.

COLENBRANDER, A.; FLETCHER, D. Low vision rehabilitation. A study guide and outline for ophthalmologists, residents and allied health personnel Anaheim. Joint Commission on Allied Health Personnel in Ophthalmology, p. 1-14, 2003. Available from:

https://pdfs.semanticscholar.org/a774/73a1ae99b2b8f9d10eddb0edb5fc169119b1.pd f. Acess in: 10 jan. 2016.

COWAN, R. E. et al. Recent trends in assistive technology for mobility. Journal of NeuroEngineering and Rehabilitation, v. 9, n. 20, p. 1-8, 2012.

CYPEL, M. C. et al. Vision status, ophthalmic assessment, and quality of life in the very old. Arq Bras Oftalmol., v. 80, n. 3, p. 159-64, 2017. 
DELOGU, F. et al. Non-visual exploration of geographic maps: Does sonification help? Disability and Rehabilitation. Assistive Technology, v. 2010; v. 5, n. 3, p. 164174, 2010.

DU TOIT, R. A Global Public Health Perspective: Facilitating Access to Assistive Technology. Optom. Vis. Sci., v. 95, n. 9, p. 883-888, 2018.

HAKOBYAN, L. et al. Mobile Assistive Technologies for the visually impaired. Survey of Ophthamlology, v. 58, n. 6, 513-518, 2013.

IBGE. Instituto Brasileiro de Geografia e Estatística. Census 2010. Available from: http://www.ibge.gov.br/home/. Acess in: 10 jan. 2016.

MEYER, C. H. et al. Healthcare "Apps" for Smartphones: Relief or toy for patients and the visual impaired? Ophthalmologe, v. 109, n. 1, p. 21-29, 2012.

ONG, S. K.; ZHANG, J.; NEE, A. Y. C. Assistive obstacle detection and navigation devices for vision-impaired users. Disability and Rehabilitation: Assistive Technology, v. 8, n. 5, p. 409-416, 2013.

PIZZARELLO, L. et al. Vision 2020: The Right to Sight: a global initiative to eliminate avoidable blindness. Arch Ophthalmol., v. 122, n. 4, p. 615-620, 2004.

STANZEL, B. V.; MEYER, C. H. Smartphones in der Augenheilkunde Ophthalmologe. Der Ophthalmologe, v. 109: 8-20. 2012.

STEVENS, G. A. et al. Global prevalence of vision impairment and blindness: magnitude and temporal trends, 1990-2010. Ophthalmology., v. 120, n. 12, p. 23772384, 2013.

STUMP, M. Low vision assistance with mobile devices. New York. 103 p. Degree of Master of Science in Computer Engineering. Department of Computer Engineering. Rochester Institute of Technology. 2011.

THOMAS, R. et al. Assistive technology for children and young people with low vision. Cochranes, v. 10 (CD011350), p. 1-28, 2014.

TRAUZETTEL-KLOSINSKI, S. Current Methods of Visual Rehabilitation. Deutsches Ärzteblatt International., v. 108, n. 51-52, p. 871-878, 2011.

WHO, World Health Organization. Deficiência visual. Available from: http://www.deficientesemacao.com/deficiencia-visual. Acess in: 10 jan. 2016.

WITTICH, W.; SOUTHALL, K.; JOHNSON, A. Usability of assistive listening devices by older adults with low vision. Disability and Rehabilitation. Assistive Technology, v. 11, n. 07, p. 564-571, 2015. 